\title{
Influence of Oxidative Stress on Stored Platelets
}

\author{
K. Manasa and R. Vani \\ Department of Biotechnology, Center for Post Graduate Studies, Jain University, No. 18/3, 9th Main, 3rd Block, \\ Jayanagar, Bangalore 560011, India
}

Correspondence should be addressed to R. Vani; tiwari.vani@gmail.com

Received 11 September 2015; Revised 16 December 2015; Accepted 5 January 2016

Academic Editor: Debra A. Hoppensteadt

Copyright (C) 2016 K. Manasa and R. Vani. This is an open access article distributed under the Creative Commons Attribution License, which permits unrestricted use, distribution, and reproduction in any medium, provided the original work is properly cited.

Platelet storage and its availability for transfusion are limited to 5-6 days. Oxidative stress (OS) is one of the causes for reduced efficacy and shelf-life of platelets. The studies on platelet storage have focused on improving the storage conditions by altering platelet storage solutions, temperature, and materials. Nevertheless, the role of OS on platelet survival during storage is still unclear. Hence, this study was conducted to investigate the influence of storage on platelets. Platelets were stored for 12 days at $22^{\circ} \mathrm{C}$. OS markers such as aggregation, superoxides, reactive oxygen species, glucose, $\mathrm{pH}$, lipid peroxidation, protein oxidation, and antioxidant enzymes were assessed. OS increased during storage as indicated by increments in aggregation, superoxides, $\mathrm{pH}$, conjugate dienes, and superoxide dismutase and decrements in glucose and catalase. Thus, platelets could endure OS till 6 days during storage, due to the antioxidant defense system. An evident increase in OS was observed from day 8 of storage, which can diminish the platelet efficacy. The present study provides an insight into the gradual changes occurring during platelet storage. This lays the foundation towards new possibilities of employing various antioxidants as additives in storage solutions.

\section{Introduction}

Platelets play an important role in maintaining hemostasis. Platelet transfusions are essential for treatment of patients with thrombocytopenia and are routinely used during surgery, chemotherapy, and treatment of various bleeding disorders. However, platelet storage in vitro and their availability for transfusion are limited to 5-6 days at $22^{\circ} \mathrm{C}$, during which platelets lose their viability and activity [1]. Changes occur in morphology, adhesion and aggregation, membrane features, and the activation and apoptotic markers during prolonged storage $[1,2]$.

Banked platelets begin to lose their function, which can be due to (i) the platelet activation during preparation and storage process or (ii) the changes in $\mathrm{pH}$ and enzyme activation of the plasma environment or (iii) both phenomena [3]. Oxidative stress (OS) is also one of the causative factors for reduced efficacy and shelf-life of stored platelets. OS leads to decrease in platelet nitric oxide which increases platelet activation and cellular production of reactive oxygen species (ROS) [4]. But whether resulting oxidative changes trigger activation and apoptosis or activation and apoptosis trigger oxidative changes during storage is still unclear [5].

There are studies on improving the storage conditions by altering platelet storage solutions, storage materials (UPX80 [6], tri-ethylhexyl-trimellitate [7], polyolefin [8], and ELX container [9], etc.), and temperatures $4-37^{\circ} \mathrm{C}[10-21]$. Few studies have reported that glucose can be a good additive for new storage formulations [22-24]. Platelet additive solutions (PAS) with different formulations have been tested and seem to be desirable over plasma for the storage of platelet concentrates [10, 25-32]. Storing platelets in additive solutions (Tyrode's buffer) diminishes the risk of infections or allergic reactions caused by platelet storage in plasma [33].

Nevertheless, platelet survival in different storage solutions is still unclear. Thus, the present study was conducted to investigate the influence of storage on platelets in Tyrode's buffer through OS markers: (i) platelet integrity: platelet aggregation, glucose, and $\mathrm{pH}$; (ii) oxidative stress: superoxides, lipid peroxidation (conjugate dienes and thiobarbituric acid reactive substances (TBARS)), protein oxidation (protein carbonyls and sulfhydryls), and antioxidant enzymes (superoxide dismutase (SOD) and catalase (CAT)). 


\section{Experimental Procedures}

Animal care and maintenance were in accordance with the ethical committee regulations.

2.1. Chemicals. Cytochrome C (Cyt C) was purchased from Sigma-Aldrich Chemicals (St. Louis, MO, USA). All other chemicals were of reagent grade and organic solvents of spectral grade.

2.2. Blood Sampling. According to Rajashekharaiah et al., [34] 4-month-old male Wistar rats were used for sampling of blood. Blood was aspirated carefully from the heart into tubes with CPDA-1 (Citrate, phosphate, dextrose, and adenine) solution.

2.3. Experimental Design. Platelets isolated from blood of five different rats $(n=5)$ were suspended in Tyrode's buffer (NaCl-140 mM; KCl-2.7 mM; $\mathrm{NaH}_{2} \mathrm{PO}_{4}-0.4$ mM; $\mathrm{NaHCO}_{3}$ $11.9 \mathrm{mM}$; D-glucose-11.1 mM) and stored in polypropylene tubes at $22^{\circ} \mathrm{C}$ for a period of 12 days, without continuous agitation. Estimation of OS was performed by assessing the biomarkers on alternate days of storage, that is, $0,2,4,6,8$, 10 , and 12 .

2.4. Isolation of Platelets. Blood was centrifuged at $1500 \mathrm{rpm}$ for $15 \mathrm{~min}$ at room temperature to obtain platelet-rich-plasma (PRP). The PRP was then centrifuged at $4000 \mathrm{rpm}$ for $15 \mathrm{~min}$ at $22^{\circ} \mathrm{C}$. The resulting platelet pellet was gently resuspended in Tyrode's buffer, $\mathrm{pH} 7.4$ [35].

2.5. Platelet Aggregation. Platelet aggregation was measured according to modified method of Born and Cross [36]. Hundred microliters of platelet sample was added to each well of the microtiter plate and incubated at $37^{\circ} \mathrm{C}$. The absorbance was recorded at $405 \mathrm{~nm}$ in shaking mode for $1.5-2 \mathrm{~min}$. The absorbance is inversely proportional to the aggregation in platelets.

2.6. Glucose. The level of glucose in platelets during storage was assessed enzymatically by GOD-POD method as described in the Autospan Gold kit and the absorbance was taken at $546 \mathrm{~nm}$ [37].

2.7. $p H . \mathrm{pH}$ of the samples were checked using Fisher Scientific pH strips [22].

2.8. Superoxides. Superoxides in the platelets were measured according to Olas and Wachowicz [38]. Two hundred microliters of Cyt C $(160 \mu \mathrm{M})$ was added to the platelets and incubated at $37^{\circ} \mathrm{C}$. The samples were centrifuged at $3500 \mathrm{rpm}$ for $5 \mathrm{~min}$. Reduction of Cyt C was measured spectrophotometrically at $550 \mathrm{~nm}$. To calculate the molar concentration of superoxide, extinction coefficient for Cyt C of $18,700 \mathrm{M}^{-1} \mathrm{~cm}^{-1}$ was used.
2.9. Conjugate Dienes. Conjugate dienes were measured according to Olas and Wachowicz [38]. Platelet samples were transferred to ether/ethanol $(1: 3 \mathrm{v} / \mathrm{v})$ mixture and vortexed. The mixture was centrifuged at $4000 \mathrm{rpm}$. The level of conjugate dienes was measured spectrophotometrically at $235 \mathrm{~nm}$.

2.10. Thiobarbituric Acid Reactive Substances (TBARS). TBARS were measured according to Olas et al. [39]. The platelet samples were cooled in an ice bath for $10 \mathrm{~min}$. The samples were then transferred to an equal volume of $20 \%$ $(\mathrm{v} / \mathrm{v})$ cold trichloroacetic acid (TCA) in $0.6 \mathrm{M} \mathrm{HCl}$ and centrifuged at $2000 \mathrm{rpm}$ for $15 \mathrm{~min}$. The supernatant was mixed with $0.2 \mathrm{~mL}$ of $0.12 \mathrm{M}$ thiobarbituric acid (TBA) in $0.26 \mathrm{M}$ Tris at $\mathrm{pH}$ 7.0. The mixture was incubated in a boiling water bath for $15 \mathrm{~min}$ and the absorbance was read at $532 \mathrm{~nm}$.

2.11. Protein Carbonyls. Protein carbonyls were measured according to Reznick and Packer [40]. Platelet samples were mixed with $2 \mathrm{~mL}$ of $10 \mathrm{mM}$ dinitrophenyl hydrazine (DNPH) in $2.5 \mathrm{M} \mathrm{HCl}$ and incubated for $1 \mathrm{~h}$ at room temperature. After incubation, $2.5 \mathrm{~mL}$ of $20 \%$ TCA was added and left in ice for $10 \mathrm{~min}$. The mixture was centrifuged at $3000 \mathrm{rpm}$ and the supernatant was discarded. The protein pellets were washed three times with ethanol : ethyl acetate $(1: 1 \mathrm{v} / \mathrm{v})$. The final precipitate was dissolved in $1 \mathrm{~mL}$ of $6 \mathrm{M}$ guanidine $\mathrm{HCl}$ in $133 \mathrm{mM}$ Tris. The absorbance was read at $370 \mathrm{~nm}$. The carbonyl content was calculated using absorption coefficient of $22,000 \mathrm{M}^{-1} \mathrm{~cm}^{-1}$.

2.12. Protein Sulfhydryls. The protein sulfhydryls were measured according to Habeeb [41]. Platelet samples were mixed with $1.5 \mathrm{~mL}$ of $0.08 \mathrm{M}$ buffer $\left(\mathrm{Na}-\mathrm{PO}_{4}, 0.5 \mathrm{mg} \mathrm{mL}\right.$ of $\mathrm{Na}_{2}$-EDTA and 2\% SDS, $\mathrm{pH} 8.0$ ) and vortexed. Then $0.1 \mathrm{~mL}$ of $5,5^{\prime}$-dithiobis-(2-nitrobenzoic acid) (DTNB) was added. This was incubated at room temperature for $15 \mathrm{~min}$. The absorbance was read at $412 \mathrm{~nm}$. Molar absorptivity of $13,600 \mathrm{M}^{-1} \mathrm{~cm}^{-1}$ was used to calculate protein sulfhydryls.

2.13. Superoxide Dismutase (SOD, EC 1.15.1.1). SOD in the platelet sample was measured according to Misra and Fridovich [42]. Platelet samples were added to $880 \mu \mathrm{L}$ of carbonate buffer $(0.05 \mathrm{M}, \mathrm{pH} 10.2,0.1 \mathrm{mM}$ EDTA). Forty microliters of epinephrine was added to the mixture and the absorbance was measured at $480 \mathrm{~nm}$ for $4 \mathrm{~min}$. SOD activity was expressed as the amount of enzyme that inhibits oxidation of epinephrine by $50 \%$ which is equal to 1 unit.

2.14. Catalase (CAT, EC 1.11.1.6). Catalase was measured according to Aebi [43]. Ten microliters of absolute ethanol was added to $100 \mu \mathrm{L}$ of platelet sample and incubated in ice bath for $30 \mathrm{~min}$. After incubation, $240 \mu \mathrm{L}$ of phosphate buffer was added to the above sample. Two hundred and fifty microliters of $0.066 \mathrm{M} \mathrm{H}_{2} \mathrm{O}_{2}$ was added just before reading and the absorbance was measured at $240 \mathrm{~nm}$. The molar extinction coefficient of $43.6 \mathrm{M}^{-1} \mathrm{~cm}^{-1}$ was used to determine the catalase activity. 


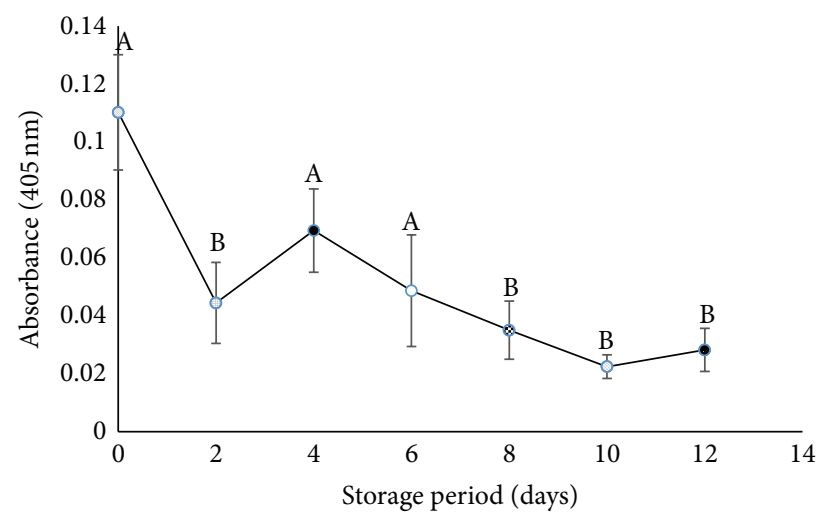

FIGURE 1: Aggregation in stored platelets. Values are mean \pm SE of five animals/group. One-way ANOVA was performed between the groups followed by Tukey-Kramer multiple comparison test, using Graph Pad Prism 6 software, and represented in upper case at $P<$ 0.05 . Those not sharing the same letters are significantly different.

2.15. Protein. The protein concentration in the samples was determined according to Lowry et al. [44].

2.16. Statistical Analyses. Results are represented as mean \pm SE. One-way ANOVA was performed between the groups for all the parameters and the results are considered significant at $P<0.05$. Tukey-Kramer multiple comparison test was performed using GraphPad Prism 6 Software.

\section{Results}

3.1. Platelet Aggregation Increased during Storage. Aggregation increased significantly by $59 \%$ (day 2), 68\% (day 8), 79\% (day 10 ), and $74 \%$ (day 12) when compared with day 0 at $P<0.05$ (Figure 1).

3.2. Superoxides Increased during Storage. Superoxides elevated significantly after day 6 of storage. There was an increase of 6-, 10-, and 3-fold on days 8, 10, and 12, respectively, against day 0 at $P<0.05$. Decrement of $60 \%$ was observed on day 12 when compared with day 10 (Figure 2).

3.3. Glucose Decreased during Storage. Glucose levels reduced significantly $(P<0.05)$ throughout storage. Glucose levels decreased on day 2 by $39 \%$ and were maintained up to day 10. Decline in glucose levels by $91 \%$ was observed on day 12 against day 0 (Table 1 ).

3.4. $p H$ Elevated with Storage. $\mathrm{pH}$ gradually elevated up to day 10 and by $42 \%$ on day 12 against day $0(P<0.05)$ (Table 1$)$.

3.5. Conjugate Dienes Increased towards End of Storage. Significant increments were observed in conjugate dienes by 24- and 13-fold on days 10 and 12, respectively, with day 0 at $P<0.05$ (Table 1 ).

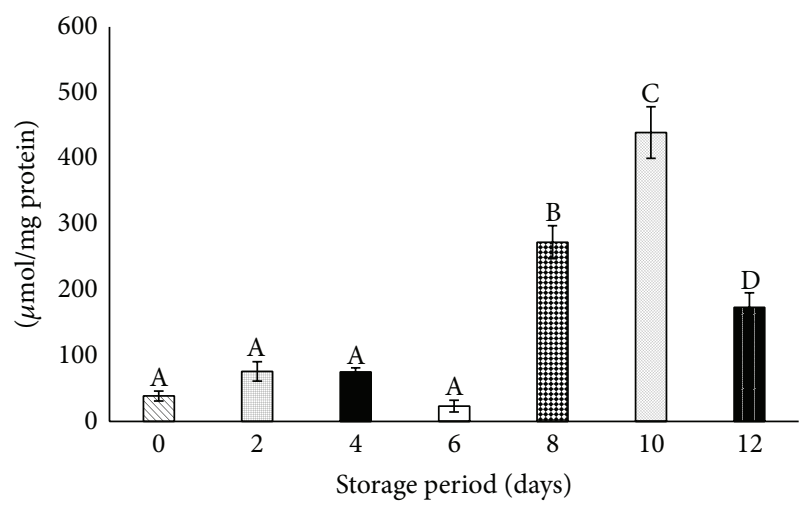

FIGURE 2: Superoxides in stored platelets. Values are mean \pm SE of five animals/group. One-way ANOVA was performed between the groups followed by Tukey-Kramer multiple comparison test, using Graph Pad Prism 6 software, and represented in upper case at $P<$ 0.05 . Those not sharing the same letters are significantly different.

3.6. TBARS Increased on Day 10. TBARS levels were maintained till day 8 but incremented by 3 -fold on day 10 against day $0(P<0.05)$ (Table 1$)$.

3.7. Protein Carbonyls Varied during Storage. Carbonyls increased by 9 -fold on day 4 against day 0 at $P<0.05$. Protein carbonyls declined on day 6 against day 4 and were maintained till day 10 . Elevation of 6 -fold was noted on day 12 against day 0 at $P<0.05$ (Table 1 ).

3.8. Protein Sulfhydryls Increased after 8 Days of Storage. Protein sulfhydryls augmented only after day 6 and elevation of 1 -fold was observed on day 12 against day $0(P<0.05)$ (Table 1).

3.9. Superoxide Dismutase Incremented after Day 6 of Storage. SOD significantly increased $(P<0.05)$ by 1 -fold on days 6,8 , 10 , and 12 with respect to day 0 (Figure 3 ).

3.10. Catalase Declined after 8 Days of Storage. Significant decreases of $93 \%$ and $95 \%$ were observed on days 8 and 12 , respectively, when compared with day 0 at $P<0.05$ (Figure 4).

\section{Discussion}

Our results showed that platelets could endure OS up to 6 days of storage and the onset of oxidative damage was noted from day 8. Platelets stored in plasma lose their functions considerably and also are exposed to infectious and allergic agents and proteolytic enzymes that can lead to premature clearance from circulation. Storing platelets in Tyrode's buffer provides optimal conditions for cell preservation and helps to control the environmental conditions during storage. Using a defined medium enhances the reproducible quality of stored platelet preparations [33]. The absence of $\mathrm{Ca}^{2+}$ in Tyrode's buffer also reduces platelet activation [45]. Platelet aggregation in our study increased in proportion to the free 
TABLE 1: Glucose, $\mathrm{pH}$, lipid peroxidation, and protein oxidation in stored platelets.

\begin{tabular}{|c|c|c|c|c|c|c|}
\hline \multirow[b]{2}{*}{ Storage Period (Days) } & \multirow[b]{2}{*}{ Glucose $(\mathrm{mmol} / \mathrm{L})$} & \multirow[b]{2}{*}{$\mathrm{pH}$} & \multicolumn{2}{|c|}{ Lipid peroxidation } & \multicolumn{2}{|c|}{ Protein oxidation } \\
\hline & & & $\begin{array}{c}\text { Conjugate dienes } \\
(\mu \mathrm{mol} / \mathrm{mg} \\
\text { protein })\end{array}$ & $\begin{array}{l}\text { TBARS } \\
(\mu \mathrm{mol} / \mathrm{mg} \\
\text { Protein })\end{array}$ & $\begin{array}{l}\text { Protein } \\
\text { carbonyls } \\
(\mu \mathrm{mol} / \mathrm{mg} \\
\text { protein })\end{array}$ & $\begin{array}{l}\text { Protein } \\
\text { sulfhydryls } \\
\text { ( } \mu \mathrm{mol} / \mathrm{mg} \\
\text { protein })\end{array}$ \\
\hline 0 & $12.22 \pm 0.7^{\mathrm{a}}$ & $7.0 \pm 0.0^{\mathrm{a}}$ & $23.20 \pm 4.7^{\mathrm{a}}$ & $9.40 \pm 3.1^{\mathrm{a}}$ & $18.45 \pm 5.7^{\mathrm{a}}$ & $251.45 \pm 48.0^{\mathrm{ab}}$ \\
\hline 2 & $7.42 \pm 0.6^{\mathrm{b}}$ & $7.0 \pm 0.0^{\mathrm{a}}$ & $28.26 \pm 11.8^{\mathrm{a}}$ & $11.31 \pm 4.8^{\mathrm{a}}$ & $93.73 \pm 25.0^{\mathrm{ac}}$ & $105.33 \pm 30.2^{\mathrm{a}}$ \\
\hline 4 & $5.80 \pm 0.1^{\mathrm{b}}$ & $8.0 \pm 0.0^{b}$ & $69.64 \pm 21.5^{\mathrm{a}}$ & $4.15 \pm 2.3^{\mathrm{a}}$ & $185.5 \pm 21.0^{\mathrm{b}}$ & $132.26 \pm 15.8^{\mathrm{a}}$ \\
\hline 6 & $5.84 \pm 0.3^{b}$ & $8.4 \pm 0.2^{\mathrm{b}}$ & $21.52 \pm 6.6^{\mathrm{a}}$ & $14.32 \pm 5.4^{\mathrm{ab}}$ & $17.61 \pm 5.5^{\mathrm{a}}$ & $244.57 \pm 63.8^{\mathrm{ab}}$ \\
\hline 8 & $7.33 \pm 0.6^{\mathrm{b}}$ & $8.4 \pm 0.2^{b}$ & $96.6 \pm 18.4^{\mathrm{a}}$ & $7.34 \pm 1.4^{\mathrm{a}}$ & $68.37 \pm 3.6^{\mathrm{ac}}$ & $392.6 \pm 46.2^{\mathrm{b}}$ \\
\hline 10 & $6.16 \pm 0.1^{b}$ & $9.0 \pm 0.0^{c}$ & $585.7 \pm 41.9^{\mathrm{b}}$ & $38.4 \pm 13.0^{\mathrm{b}}$ & $64.77 \pm 14.7^{\mathrm{ac}}$ & $350.18 \pm 37.5^{\mathrm{b}}$ \\
\hline 12 & $1.05 \pm 0.2^{c}$ & $10.0 \pm 0.0^{\mathrm{d}}$ & $330.9 \pm 71.6^{\mathrm{c}}$ & $4.22 \pm 1.0^{\mathrm{a}}$ & $146.78 \pm 33.8^{\mathrm{bc}}$ & $528.18 \pm 55.5^{\mathrm{c}}$ \\
\hline
\end{tabular}

Values are expressed as mean $\pm \mathrm{SE}$ of five animals/group. Changes between groups were analyzed by one-way ANOVA followed by Tukey-Kramer multiple comparison test, using GraphPad Prism 6 software. $P<0.05$ was considered significant. Changes between the groups are represented in lower case. Those not sharing the same letters are significantly different.

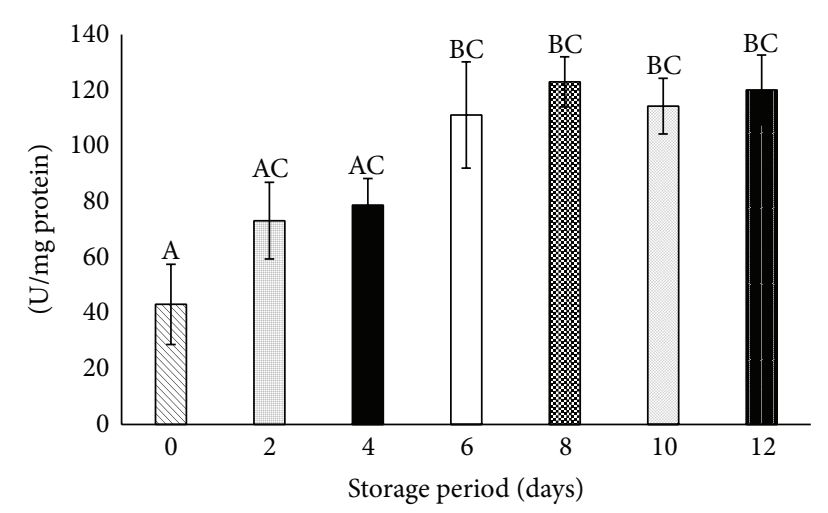

Figure 3: Superoxide dismutase in stored platelets. Values are mean \pm SE of five animals/group. One-way ANOVA was performed between the groups followed by Tukey-Kramer multiple comparison test, using Graph Pad Prism 6 software, and represented in upper case at $P<0.05$. Those not sharing the same letters are significantly different.

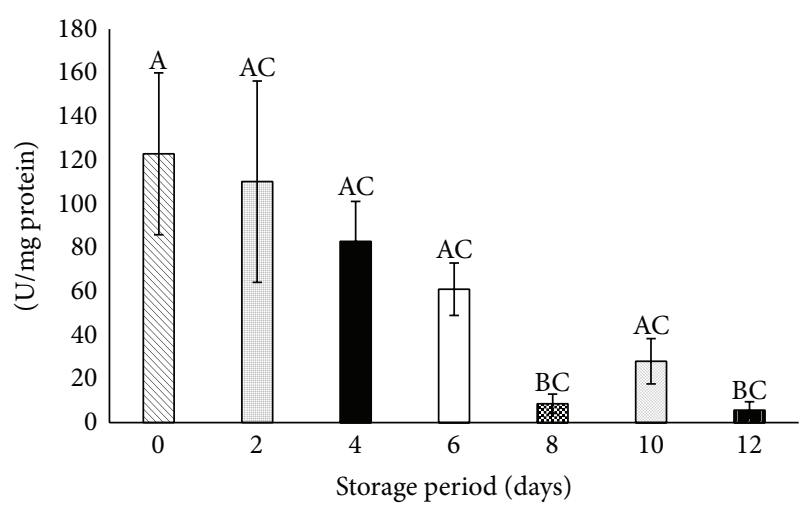

FIgURE 4: Catalase in stored platelets. Values are mean \pm SE of five animals/group. One-way ANOVA was performed between the groups followed by Tukey-Kramer multiple comparison test, using Graph Pad Prism 6 software, and represented in upper case at $P<$ 0.05 . Those not sharing the same letters are significantly different. radical generation during storage, as observed in our results of increased superoxides during storage. The decrease in superoxides on day 12 against day 10 can be due to the decrease in number of platelets. The decrease in glucose level is directly proportional to the energy levels and platelet count [24]. The ideal $\mathrm{pH}$ for platelet transfusion should be between 6.4 and 7.4 at $22^{\circ} \mathrm{C}$ [46]. $\mathrm{pH}$ increased up to 10.0 by day 12 of storage. This can be due to the depletion of glucose in the medium, as glycolysis produces lactate, which reduces the $\mathrm{pH}$ of stored platelets [46]. The factors such as bacterial contamination, storage bag gas permeability [47], and platelet content in storage bag [48] can also affect the $\mathrm{pH}$ of platelets during storage.

The primary (conjugate dienes) and secondary (TBARS) products of lipid peroxidation increased at the end of storage. This can be due to elevations in superoxides and other ROS generation beyond the antioxidant defense, as polyunsaturated fatty acids (PUFAs) are the most oxygen sensitive constituents of cells and easily suffer oxidation [49].

Reactive carbonyl groups in proteins are formed due to oxidation of arginine, lysine, threonine, or proline by the ROS in platelets [50]. The increase in carbonyls on day 4 may be due to the generation of free radicals which in turn triggers the antioxidant defenses (hormesis effect). This was elucidated in our results of day 6 where carbonyls decremented, which may be due to the activation of antioxidant defenses [51]. The elevated carbonyls on day 12 can be due to increased free radicals, overwhelming the platelet antioxidant system.

Sulfhydryls are the potential sites of reversible oxidative modification by S-glutathiolation and S-nitrosylation [52]. The augmented levels of sulfhydryls by the end of storage can be due to the activated or aggregated platelets that are known to exhibit increased surface sulfhydryls, especially protein disulfide isomerase (PDI) sulfhydryls [53]. This is in correlation with our results of increased platelet aggregation during storage.

An increase in SOD activity is the result of elevated free radicals [54]. SOD incremented by day 6 of storage and was maintained till day 12 . This is in accordance with the elevation 
in superoxide levels as observed in our results. The level of superoxide regulates the rate of SOD activity [55]. CAT is activated at higher concentrations of $\mathrm{H}_{2} \mathrm{O}_{2}$ [56] and at lower concentrations, $\mathrm{H}_{2} \mathrm{O}_{2}$ is scavenged by glutathione peroxidase (GSH-Px) [57]. CAT activity decreased by the end of storage though there was an increase in SOD activity which can be due to the $\mathrm{H}_{2} \mathrm{O}_{2}$ scavenging action of GSH-Px.

\section{Conclusion}

Platelets could endure OS till 6 days during storage, due to the antioxidant defense system. An evident increase in OS was observed from day 8 of storage, which can diminish the platelet efficacy.

The present study provides an insight into the gradual changes occurring during platelet storage. This lays the foundation towards new possibilities of employing various antioxidants as additives in storage solutions to attenuate OS and hence enhance the stability and efficacy of stored platelets.

\section{Conflict of Interests}

The authors report no conflict of interests.

\section{Acknowledgments}

The authors acknowledge Dr. Leela Iyengar, Ms. Soumya Ravikumar, Mr. Carl Hsieh, and Jain University for their support.

\section{References}

[1] J. N. Thon, P. Schubert, and D. V. Devine, "Platelet storage lesion: a new understanding from a proteomic perspective," Transfusion Medicine Reviews, vol. 22, no. 4, pp. 268-279, 2008.

[2] E. M. Martín-Valmaseda, J. Sánchez-Yagüe, M. C. Rodríguez, F. P. Gómez, and M. Llanillo, "Comparison between in vitro lipid peroxidation in fresh sheep platelets and peroxidative processes during sheep platelet ageing under storage at $4^{\circ} \mathrm{C}$," Biochimica et Biophysica Acta: Biomembranes, vol. 1419, no. 2, pp. 313-324, 1999.

[3] J. N. George, "Platelet membrane glycoproteins: alteration during storage of human platelet concentrates," Thrombosis Research, vol. 8, no. 5, pp. 719-724, 1976.

[4] J. E. Freedman, J. Loscalzo, M. R. Barnard, C. Alpert, J. F. Keaney Jr., and A. D. Michelson, "Nitric oxide released from activated platelets inhibits platelet recruitment," The Journal of Clinical Investigation, vol. 100, no. 2, pp. 350-356, 1997.

[5] B. Goker, D. Ozsavci, A. Sener et al., "Oxidative alterations during human platelet storage," Marmara Pharmaceutical Journal, vol. 15, pp. 38-42, 2011.

[6] E. H. Kostelijk, C. W. N. Gouwerok, H. A. Veldman, and D. De Korte, "Comparison between a new PVC platelet storage container (UPX80) and a polyolefin container," Transfusion Medicine, vol. 10, no. 2, pp. 131-139, 2000.

[7] H. Singh, R. Chaudhary, and V. Ray, "Evaluation of platelet storage lesions in platelet concentrates stored for seven days," The Indian Journal of Medical Research, vol. 118, pp. 243-246, 2003.
[8] T. Yuasa, H. Ohto, R. Yasunaga, T. Kai, N. Shirahama, and T. Ogata, "Improved extension of platelet storage in a polyolefin container with higher oxygen permeability," British Journal of Haematology, vol. 126, no. 1, pp. 153-159, 2004.

[9] H. Alhumaidan, T. Cheves, S. Holme, and J. D. Sweeney, "Manufacture of pooled platelets in additive solution and storage in an ELX container after an overnight warm temperature hold of platelet-rich plasma," American Journal of Clinical Pathology, vol. 136, no. 4, pp. 638-645, 2011.

[10] T. Chandra, A. Gupta, and A. Kumar, "Extended shelf life of random donor platelets stored for 7 days in platelet additive solution at different temperatures," Biomedical Journal, vol. 37, no. 4, pp. 211-217, 2014.

[11] S. Murphy and F. H. Gardner, "Effect of storage temperature on maintenance of platelet viability-deleterious effect of refrigerated storage," The New England Journal of Medicine, vol. 280, no. 20, pp. 1094-1098, 1969.

[12] G. A. Becker, M. Tuccelli, T. Kunicki et al., "Studies of platelet concentrates stored at $22^{\circ} \mathrm{C}$ and $4^{\circ} \mathrm{C}$," Transfusion, vol. 13, pp. 61-68, 1973.

[13] S. Holme, K. Vaidja, and S. Murphy, "Platelet storage at $22^{\circ} \mathrm{C}$ : effect of type of agitation on morphology, viability and function in vitro," Blood, vol. 52, no. 2, pp. 425-435, 1978.

[14] A. K. Rao and S. Murphy, "Secretion defect in platelets stored at $4^{\circ} \mathrm{C}$," Thrombosis and Haemostasis, vol. 47, no. 3, pp. 221-225, 1982.

[15] L. M. Currie, J. R. Harper, H. Allan, and J. Connor, "Inhibition of cytokine accumulation and bacterial growth during storage of platelet concentrates at $4^{\circ} \mathrm{C}$ with retention of in vitro functional activity," Transfusion, vol. 37, no. 1, pp. 18-24, 1997.

[16] A. M. Bertino, X. Q. Qi, J. Li, Y. Xia, and D. J. Kuter, "Apoptotic markers are increased in platelets stored at $37^{\circ} \mathrm{C}$," Transfusion, vol. 43, no. 7, pp. 857-866, 2003.

[17] J. W. Choi and S. H. Pai, "Influence of storage temperature on the responsiveness of human platelets to agonists," Annals of Clinical and Laboratory Science, vol. 33, no. 1, pp. 79-85, 2003.

[18] K. M. Hoffmeister, T. W. Felbinger, H. Falet et al., "The clearance mechanism of chilled blood platelets," Cell, vol. 112, no. 1, pp. 8797, 2003.

[19] J.-N. Zhang, J. Wood, A. L. Bergeron et al., "Effects of low temperature on shear-induced platelet aggregation and activation," The Journal of Trauma-Injury, Infection \& Critical Care, vol. 57, no. 2, pp. 216-223, 2004.

[20] P. Sandgren, A. Shanwell, and H. Gulliksson, "Storage of buffy coat-derived platelets in additive solutions: in vitro effects of storage at $4^{\circ}$ C", Transfusion, vol. 46, no. 5, pp. 828-834, 2006.

[21] A. M. Babic, E. C. Josefsson, W. Bergmeier et al., "In vitro function and phagocytosis of galactosylated platelet concentrates after long-term refrigeration," Transfusion, vol. 47, no. 3, pp. 442-451, 2007.

[22] A. M. Amorini, M. Tuttobene, G. Lazzarino, and G. Denti, "Evaluation of biochemical parameters in platelet concentrates stored in glucose solution," Blood Transfusion, vol. 5, no. 1, pp. 24-32, 2007.

[23] A. M. Amorini, M. Tuttobene, F. M. Tomasello et al., "Glucose ameliorates the metabolic profile and mitochondrial function of platelet concentrates during storage in autologous plasma," Blood Transfusion, vol. 11, no. 1, pp. 61-70, 2013.

[24] C. Saunders, G. Rowe, K. Wilkins, and P. Collins, "Impact of glucose and acetate on the characteristics of the platelet storage lesion in platelets suspended in additive solutions with minimal plasma," Vox Sanguinis, vol. 105, no. 1, pp. 1-10, 2013. 
[25] S. Holme, W. A. Heaton, and M. Courtright, "Improved in vivo and in vitro viability of platelet concentrates stored for seven days in a platelet additive solution," British Journal of Haematology, vol. 66, no. 2, pp. 233-238, 1987.

[26] G. Rock, J. White, and R. Labow, "Storage of platelets in balanced salt solutions: a simple platelet storage medium," Transfusion, vol. 31, no. 1, pp. 21-25, 1991.

[27] J. De Wildt-Eggen, J. G. Schrijver, M. Bins, and H. Gulliksson, "Storage of platelets in additive solutions: effects of magnesium and/or potassium," Transfusion, vol. 42, no. 1, pp. 76-80, 2002.

[28] P. F. Van der Meer, R. N. I. Pietersz, and H. W. Reesink, "Storage of platelets in additive solution for up to 12 days with maintenance of good in-vitro quality," Transfusion, vol. 44, no. 8, pp. 1204-1211, 2004.

[29] J.-L. H. Kerkhoffs, J. C. Eikenboom, M. S. Schipperus et al., "A multicenter randomized study of the efficacy of transfusions with platelets stored in platelet additive solution II versus plasma," Blood, vol. 108, no. 9, pp. 3210-3215, 2006.

[30] J. Sweeney, N. Kouttab, S. Holme, J. Kurtis, T. Cheves, and E. Nelson, "Storage of platelet-rich plasma-derived platelet concentrate pools in plasma and additive solution," Transfusion, vol. 46, no. 5, pp. 835-840, 2006.

[31] A. Gupta, T. Chandra, and A. Kumar, "In vitro function of random donor platelets stored for 7 days in composol platelet additive solution," Asian Journal of Transfusion Science, vol. 5, no. 1, pp. 11-14, 2011.

[32] S. J. Slichter, J. Corson, M. K. Jones et al., "Exploratory studies of extended storage of apheresis platelets in a platelet additive solution (PAS)," Blood, vol. 123, no. 2, pp. 271-280, 2014.

[33] G. Rock, S. D. Swenson, and G. A. Adams, "Platelet storage in a plasma-free medium,” Transfusion, vol. 25, no. 6, pp. 551-556, 1985.

[34] V. Rajashekharaiah, A. A. Koshy, A. K. Koushik et al., "The efficacy of erythrocytes isolated from blood stored under blood bank conditions," Transfusion and Apheresis Science, vol. 47, no. 3, pp. 359-364, 2012.

[35] A. M. D. Carneiro and R. D. Blakely, "Serotonin-, protein kinase C-, and Hic-5-associated redistribution of the platelet serotonin transporter," The Journal of Biological Chemistry, vol. 281, no. 34, pp. 24769-24780, 2006.

[36] G. V. R. Born and M. J. Cross, "The aggregation of blood platelets," The Journal of physiology, vol. 168, pp. 178-195, 1963.

[37] A. Basak, "Development of a rapid and inexpensive plasma glucose estimation by two-point kinetic method based on glucose oxidase-peroxidase enzymes," Indian Journal of Clinical Biochemistry, vol. 22, no. 1, pp. 156-160, 2007.

[38] B. Olas and B. Wachowicz, "Resveratrol and vitamin C as antioxidants in blood platelets," Thrombosis Research, vol. 106, no. 2, pp. 143-148, 2002.

[39] B. Olas, P. Nowak, J. Kolodziejczyk, M. Ponczek, and B. Wachowicz, "Protective effects of resveratrol against oxidative/ nitrative modifications of plasma proteins and lipids exposed to peroxynitrite," The Journal of Nutritional Biochemistry, vol. 17, no. 2, pp. 96-102, 2006.

[40] A. Z. Reznick and L. Packer, "Oxidative damage to proteins: spectrophotometric method for carbonyl assay," Methods in Enzymology, vol. 233, pp. 357-361, 1994.

[41] A. F. S. A. Habeeb, "Reaction of protein sulfhydryl groups with Ellman's reagent," in Methods in Enzymology, vol. 25, chapter 34, pp. 457-464, Academic Press, Cambridge, Mass, USA, 1972.
[42] H. P. Misra and I. Fridovich, "The role of superoxide anion in the autoxidation of epinephrine and a simple assay for superoxide dismutase," The Journal of Biological Chemistry, vol. 247, no. 10, pp. 3170-3175, 1972.

[43] H. Aebi, "Catalase in vitro," in Methods in Enzymology, L. Packer, Ed., vol. 105, pp. 121-126, Academic Press, Cambridge, Mass, USA, 1984.

[44] O. H. Lowry, N. J. Rosebrough, A. L. Farr, and R. J. Randall, "Protein measurement with the Folin phenol reagent," The Journal of Biological Chemistry, vol. 193, no. 1, pp. 265-275, 1951.

[45] G. Grynkiewicz, M. Poenie, and R. Y. Tsien, "A new generation of $\mathrm{Ca}^{2+}$ indicators with greatly improved fluorescence properties," The Journal of Biological Chemistry, vol. 260, no. 6, pp. 3440-3450, 1985.

[46] D. W. C. Dekkers, I. M. De Cuyper, P. F. Van Der Meer, A. J. Verhoeven, and D. De Korte, "Influence of $\mathrm{pH}$ on stored human platelets," Transfusion, vol. 47, no. 10, pp. 1889-1895, 2007.

[47] S. Murphy and F. H. Gardner, "Platelet storage at $22^{\circ} \mathrm{C}$ : role of gas transport across plastic containers in maintenance of viability," Blood, vol. 46, no. 2, pp. 209-218, 1975.

[48] L. J. Dumont and T. VandenBroeke, "Seven-day storage of apheresis platelets: report of an in vitro study," Transfusion, vol. 43, no. 2, pp. 143-150, 2003.

[49] G. Spiteller, "Peroxyl radicals: inductors of neurodegenerative and other inflammatory diseases. Their origin and how they transform cholesterol, phospholipids, plasmalogens, polyunsaturated fatty acids, sugars, and proteins into deleterious products," Free Radical Biology and Medicine, vol. 41, no. 3, pp. 362-387, 2006.

[50] N. Alexandru, A. Constantin, and D. Popov, "Carbonylation of platelet proteins occurs as consequence of oxidative stress and thrombin activation, and is stimulated by ageing and type 2 diabetes," Clinical Chemistry and Laboratory Medicine, vol. 46, no. 4, pp. 528-536, 2008.

[51] S. Chevion, D. S. Moran, Y. Heled et al., "Plasma antioxidant status and cell injury after severe physical exercise," Proceedings of the National Academy of Sciences of the United States of America, vol. 100, no. 9, pp. 5119-5123, 2003.

[52] J. A. Thomas and R. J. Mallis, "Aging and oxidation of reactive protein sulfhydryls," Experimental Gerontology, vol. 36, no. 9, pp. 1519-1526, 2001.

[53] D. W. Essex, "The role of thiols and disulfides in platelet function," Antioxidants and Redox Signaling, vol. 6, no. 4, pp. 736-746, 2004.

[54] A. Gürlek, E. Tutar, E. Akçil et al., "The effects of L-carnitine treatment on left ventricular function and erythrocyte superoxide dismutase activity in patients with ischemic cardiomyopathy," European Journal of Heart Failure, vol. 2, no. 2, pp. 189-193, 2000.

[55] S. M. El-Bahr, "Biochemistry of free radicals and oxidative stress," Science International, vol. 1, no. 5, pp. 111-117, 2013.

[56] M. Kurata, M. Suzuki, and N. S. Agar, "Antioxidant systems and erythrocyte life-span in mammals," Comparative Biochemistry and Physiology Part B: Comparative Biochemistry, vol. 106, no. 3, pp. 477-487, 1993.

[57] K. Rahman, "Studies on free radicals, antioxidants and cofactors," Clinical Interventions in Aging, vol. 2, no. 2, pp. 219-236, 2007. 


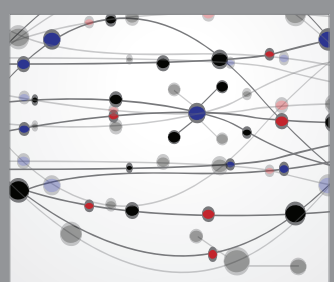

The Scientific World Journal
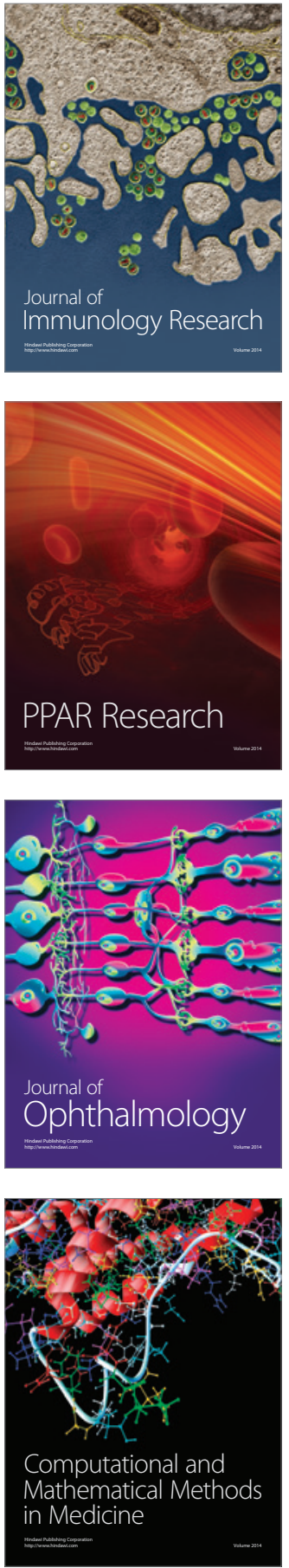

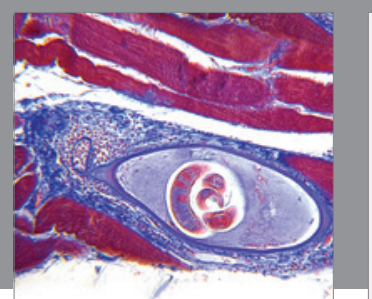

Gastroenterology Research and Practice

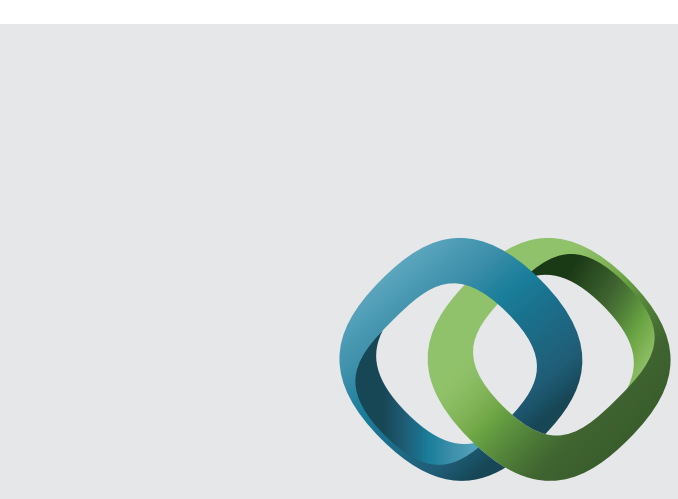

\section{Hindawi}

Submit your manuscripts at

http://www.hindawi.com

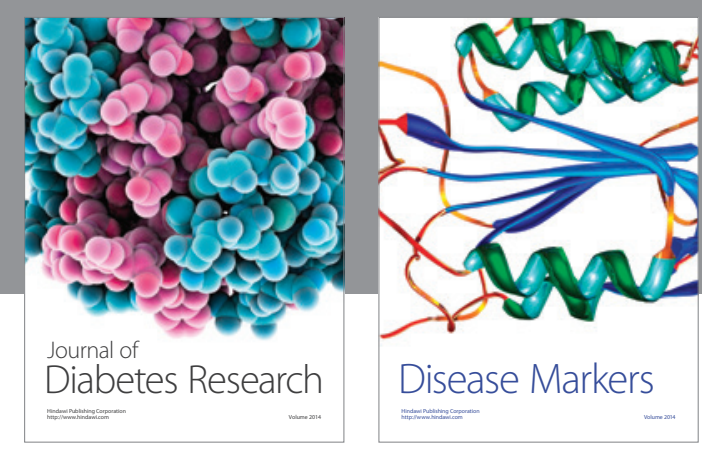

Disease Markers
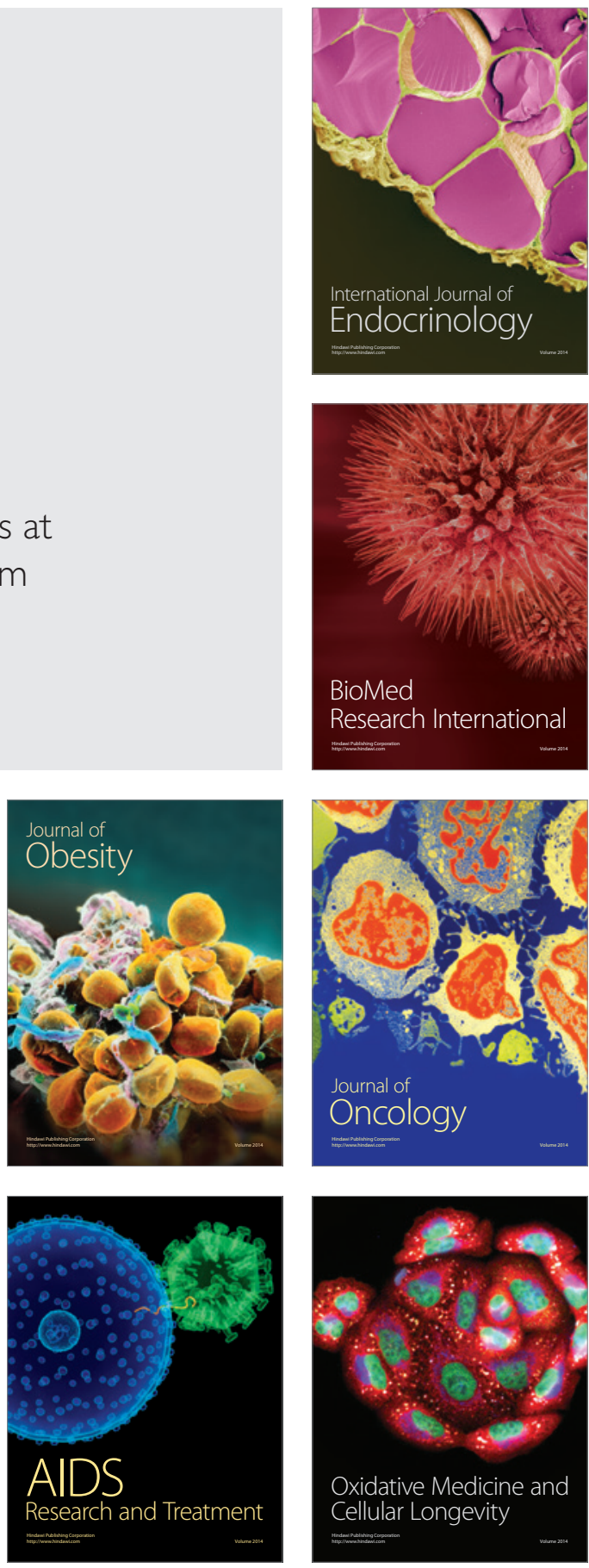